\title{
The Effectiveness of an Extensive Reading Remedial Program in Developing Prep Stage students' English reading proficiency.
}

\author{
Heba Hesham Mohamed Hassan Gad \\ An EFL Teacher \\ heba46089@gmail.com \\ Dr: Mohamed Hassan Ibrahim \\ Prof. of Curriculum and Instruction \\ (TEFL) Faculty of Education \\ Zagazig University \\ mhihasan@,zu.edu.eg
}

\begin{abstract}
:
The current study aimed at investigating the effectiveness of an Extensive reading Remedial Program in developing prep stage students' English reading proficiency. The study adopted quasi-experimental design of the two groups. The participants of the study were 60 third year prep stage students from EL Shaheed Samah Mobshir Prep School For Girls in EL Kanayat City who were equally divided into an experimental group and a control group. The experimental group was taught using the extensive Reading Remedial Program whereas the control group received regular instruction. The instrument of the study was a reading proficiency pre-post test. The results revealed that the extensive reading remedial program was effective in developing prep stage students' English reading proficiency.
\end{abstract}


Keywords: Reading Proficiency, extensive reading remedial program,Egypt.

\section{فاعلية برنامج القراءة المكثفة العلاجى لتنمية الطلاقة القرائية باللغة الانجليزية لتلاميد المرحلة الاعدادية.}

تهدف الدراسـة الحالية إلى دراسـة فاعلية برنامـج القراءة المكثفة العلاجى

لتتميـة الطلاقة القرائيـة باللغـة الانجليزيـة لتلاميد المرحلة الاعداديـة. و استخلدمت الدراسلة المنهج التجريبى القائم على مـجموعتين فى تصهيمـه وقد ساهم فى الدراسـة التجربية •ج تلميدة من تلاميذات المرحلة الاعدادية يهثلن صفين دراسسيين من تلاميذ مدرسـة الشهيد سـامح مباشر الاعدادية للبنات بمدينة القنايات وتم اختيا التلميدات ليهثلن مجموعتين بحيث تهثل المجموعة الاولى المجموعة التجربية

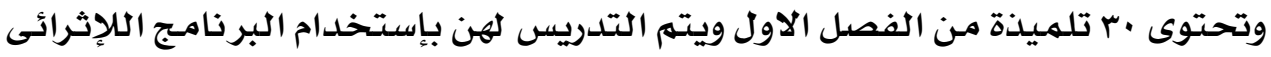
بينما المجموعة الاخرى وهى المجموعة الضابطة مكوذة من ، تلميذة من الفصل التانى ويتم التدريس لهن بالطريقة المعتادة و استمـرت الدراسلة التجربية لمدة ج اسـابيع و اعتمدت الدراسلة على اداة اختبار الطلاقة القرائية كأختبار قبلى وبعدى وتم اعدادة طبقا لأسس الكفاءة القرائية وتم الموافقة عليـة من قبل المحكمـين وقياس صدقه وثباته. الكلمات المفتاحية: الطلاقة القرائية ، و برنامـج القراءة الإثرائية. 


\section{Introduction}

Reading is the ability to read and interpret meaning from varied texts.

The National Assessment of Educational Progress (NAEP) defines reading as follows: Reading is an active and complex process that involves :(a) understanding written text ,(b) developing and interpreting meaning, (c) using meaning appropriate to type of text, purpose, and situation.

According to Wixson, Peters, Weber, \& Roeber, (1987) reading is the process of constructing meaning through the dynamic interaction among:(1) the reader's existing knowledge (2)the information suggested by the text being read and (3) the context of the reading situation. Anderson, Hiebert, Scott, \& Wilkinson,(1985) define reading as the process of constructing meaning from written texts. It is a complex skill requiring the coordination of a number of interrelated sources of information.

Reading literacy is defined as "understanding, using, and reflecting on written texts, in order to achieve one's goals, to develop one's knowledge and potential, and to participate in society" (Therrien, 2004). According to Therrien, in order to 
achieve literacy there are five important skills one must learn: phonemic awareness, phonics, vocabulary instruction, text comprehension strategies, and reading fluency. A review of literature has shown that literacy is not simply a basic skill but rather a goal and a functional means in education and individual development, both within and outside school, today and later in life, in further education, at work and in leisure activities. Reading literacy is not only a foundation for basic learning, but also a prerequisite for successful participation in most areas of youth or adult life (Linnakyla et al., 2004).

The future success of children lies in the ability to read proficiently and understand what is read. Studies show that at least one out of five students has significant difficulty in reading acquisition (Therrien, 2004). Providing an enrichment reading programs is imperative to improve both reading fluency and reading comprehension, particularly to prep stage students, because fluency and comprehension are particularly important at this stage of development and early intervention can impact the progression of reading difficulties.

In addition to supporting students' reading skills, it is also important to provide evidence for the efficacy of these 
programs. Because it is not uncommon for school counselors to be asked to assist with administrative duties, rather than provide counseling programs to promote student success, establishing evidence-based programs will support the continuation of these activities for school counselors. Further, as resources for education decline, it becomes increasingly important for school counselors to be able to demonstrate the impact of their programs on student success by providing evidence from program evaluations to support programs.

\section{Extensive reading:}

Many researchers have emphasized the importance of including extensive reading in foreign language curricula (Day \& Bamford, 1998; Grabe, 1995b; Krashen, 1982; Paran, 1996) and numerous studies have shown the effectiveness of extensive reading in contexts of English as a second or foreign language (Elley\&Mangubhai, 1981a; Hitosugi\& Day, 2004; Mason \& Krashen, 1997). Although there are variations in the ways in which an extensive reading is administered, extensive reading programs share the basic tenet that learners self- select materials within their "linguistic capabilities" from a collection of graded readers (Day and Bamford, 1998: 126) or learners are exposed to "large quantities of materials within their linguistic 
competence" (Grabe and Stoller, 2002:259). According to Nation (2005), during extensive reading, students should be interested in what they are reading and should be reading with their attention on the meaning of the text rather than on learning the language features of the text. Richards and Schmidt (2002) state that extensive reading is intended to develop good reading habits, to build up knowledge of vocabulary and structure, and encourage a liking for reading . Alderson and Urquhart (1984: 120) suggest that students might be free to choose their own reading material and even bring it from outside the classroom, and that the teacher might abandon formal questioning on the texts. Day and Bamford (1998) characterize extensive reading as involving a large quantity of varied, self-selected, enjoyable reading at a reasonably fluent speed.

There is now plenty of evidence that extensive reading can result in a variety of substantial language proficiency and comprehension. A study by Hayashi (1999) of the effects of extensive reading on Japanese university students' English proficiency found that students who reported reading more English books experienced significantly greater improvement in reading ability and vocabulary knowledge than 
those who reported reading less, as measured by pre-test and post-test.

The same perception towards extensive reading was held by the students investigated by McQuillan (1994). They reported that extensive reading to be not only more pleasurable, but also beneficial for language acquisition than instruction in grammar. Stanovich (2000) and his colleagues have demonstrated in multiple studies that the amount of people's overall exposure to print has a direct relation to their vocabulary knowledge and comprehension abilities. In examining the research on in-school reading and out-of- school self-reported free voluntary reading conducted in many different countries, Krashen (1993) concludes free voluntary reading or sustained independent reading results in better reading comprehension, writing style, vocabulary, spelling, and grammatical development.

However, the most convincing evidence for the benefits of extensive reading comes from the "book flood" studies (Elly\&Mangubhai, 1981b, 1983), which examined the effect of extensive reading on the English language proficiency by giving Fijian school children a large number of high-interest story 
books in English. These studies provide evidence of the remarkable increase on measures of language use, language knowledge as well as academic performance. In a repeated study conducted in Singapore, Elley (1991) found the students made significantly more gains in vocabulary and other language skills than the control groups. Day, Omura, and Hiramuatsu (1991) studied 191 high-school and 397 university Japanese EFL students engaged in sustained silent reading for pleasure. At the end of the treatment, they found that students in the experimental group scored significantly higher than those in the control group in correctly identifying the meaning of target vocabulary items. In an experiment comparing the improvement of reading comprehension by Japanese college freshmen taught by either a skills-based or extensive reading procedure, Bobb and Susser (1989) suggest that extensive reading may be at least as effective as skillsbuilding, with the important advantage that it is more interesting for learners.

Positive effects of extensive reading on facilitating growth of learners' attitudes towards reading and increasing their motivation to read have also been reported (Cho and 
Krashen, 1994; Mason \& Krashen, 1997; Hayashi, 1999; Hedge, 1985; Constantino, 1994; Day \& Bamford, 1998). With specific reference to reading fluency development, extensive reading has shown to be effective in increasing reading speed and comprehension (Bell, 2001; Elly and Mangubhai, 1983; Robb and Susser, 1989). Nuttall (1996: 127) posits a "vicious circle" to describe readers who cannot develop good reading skills. Slow readers do not read much, and if they do not read much, they do not understand. If they do not understand, then they cannot enjoy reading. Day and Bamford (1998) note that it is only through the actual reading experience that $\mathrm{L} 2$ or FL readers can acquire the complex linguistic, world, and topical knowledge needed to improve their reading skills. Thus, for theoretical and pedagogical reasons and based on implications from research on instructional issues, extensive reading is one of the effective methods to make up for some of the limitations of the reading done in class and to develop EFL students' reading abilities in university settings.

Extensive reading is a form of learning from meaningfocused input (Nation, 2005). In this program, extensive reading is viewed as an approach to teach reading in which the purpose is Sustained Silent Reading, pleasure reading (Mikuleck, 1990) 
or free voluntary reading (Krashen, 1993). Therefore, the principal goal is to motivate students to read and enjoy reading in order to develop their reading ability. Because of this, reading is a pleasurable activity for students, promoted as much as possible by the teacher.

The features of the extensive reading program correspond with most of Day and Bamford's (2002) “Top Ten Principles for Teaching Extensive Reading", which include the fact that eading material should be within the learners' reading competence, that students are allowed to choose what they want to read, that they read as much as possible, that teachers orient and guide their students, that reading is individual and silent, that the purpose of reading is for pleasure, information and general understanding, that reading is its own reward, and hence, don't include the answering of comprehension questions as part of the activity as well as that the teacher is a role model of a reader.

Extensive reading can only occur if $95 \%-98 \%$ of the running words in the text are already familiar to the learner or no burden to the learner ( $\mathrm{Hu}$ and Nation, 2000). Nuttall (1982) recommends $1 \%$ unfamiliar words for texts used in extensive 
reading. Laufer (1989) describes a study which found that below the level of $95 \%$ understanding of words in a text, comprehension was unsatisfactory. At any rate, the minimum 95\% comprehension figure is the guide which is adopted in the extensive reading program. Clearly, in order to achieve this level of comprehension, students whose language proficiency is below a certain level will need to read simplified texts. Graded readers are an obvious choice with controlled vocabulary and can match students' proficiency levels. Hirsh and Nation (1992) found learners would need a vocabulary of well over 2,000 words to read the easiest fiction novels written for teenagers. This shows it is only by reading graded readers that learners like the freshman non-English majors who do extensive reading at intermediate stages of proficiency can have the density of known words that is essential for extensive reading. Above all, according to Nation (2005), learning from extensive reading should meet the following conditions: focusing on the meaning of the text, understanding the type of learning that can occur through such reading, having interesting and engaging books, getting learners to do large quantities of reading at an appropriate level, and making sure that learning from reading is supported by other kinds of learning. In order to meet the 
conditions needed for learning from extensive reading at the student' proficiency levels, it is essential to make use of simplified texts (Nation, 2005). Obviously, interesting and wellwritten graded readers are such simplified texts and are likely to represent the most favorable conditions for reading.

Extensive reading should ensure that students have opportunities to read at their level, on topic they select, without tests, homework or other measures of learning (Field, 2002). The students' experience of reading the text is at the center of the extensive reading experience, just as it is in reading in every day life. For this reason, extensive reading is not usually followed by comprehension questions (Day \& Bamford, 2002). But how can teachers motivate students to read more and monitor their reading? Here are some of the techniques and procedures that can be effectively used. Firstly, the teacher can ask students to fill out a short record form indicating the name of the book they have just read, its level, how long it took to read, and a brief comment on the quality of the book. This allows the student and the teacher to see at a glance how much has been read over a period of time. Secondly, students are required to present an oral report on each book they read to the 
class or to a reading group. These reports cover questions like what the name of the book is, what type of story it is, where and when it is set, whether it is enjoyable or well written and who would like to read. Thirdly, discussion groups consisting of four or five students can be organized to bring students together who have read the same book.

As a result of the discussion, students can prepare an oral book report or a written review to present to others in the class. These activities can also help students improve their speaking and writing skills. Smith (1988: 277) notes that there is evidence that "writing is one way of promoting engagement with a text, which leads to better comprehension." Fourthly, individual counseling can provide the teacher with an opportunity to ask students about their reading experience, their progress and problems, and accordingly to approach solutions. This can be done while the rest of the class are engaged in silent reading. Finally, rewards can be given to the students for the quantity of reading they do. This will keep students excited about reading and eager to read more.

Day and Bamford (1998) credited Harold Palmer as the first to use the term extensive in referring to a large amount of reading with a focus on the meaning of the text. For Palmer, 
reading extensively has the advantage of being both informative and pleasurable. In other words, ER has real-world purposes in reading. Day and Bamford (2002, pp. 137-140) posited 10 principles of ER: The reading material is easy; a variety of reading material on a wide range of topics must be available; learners choose what they want to read; learners read as much as possible; the purpose of reading is usually related to pleasure, information, and general understanding; reading is its own reward; reading speed is usually faster rather than slower; reading is individual and silent; teachers orient and guide their students; and the teacher is a role model of a reader.

They suggested that teachers have students avoid using dictionaries and train them to skip unknown words. This is in contrast to the traditional practice in English language teaching pedagogy, which encourages students to try to guess words in context as much as they can. Furthermore, teachers should encourage students to simply stop reading if texts they are reading are not interesting. Following these principles and tips, ER studies have shown that their participants improved in areas such as reading comprehension, expanding vocabulary knowledge, and enhancing writing skills. Moreover, the studies 
reported that students who engaged in ER gained positive attitudes towards reading and increased their motivation to read.

Sheu (2003) conducted a study on junior high school students in Taiwan. The participants' English proficiency was at a beginning level. There were two treatment groups and one control group in this study. The participants in the first treatment group read graded readers, and the participants in the second treatment group read books for native English-speaking children. There was no mention of the duration of the study. The participants in the treatment groups read books during classes, but not outside of school. Sheu used t tests to compare mean differences between the pretests and posttest within groups. The mean rate in the posttests improved from 59.7 to $95.8 \mathrm{wpm}$ in the first treatment group, from 98.6 to $136.0 \mathrm{wpm}$ in the second treatment group, and from 85.2 to $118.6 \mathrm{wpm}$ in the control group. The mean differences of all three groups were statistically significant. For measuring rate, he adopted Nuttall's assessment. In this assessment, calculating wpm was done by dividing the number of words in the text by the number of 10second intervals the participants spent in reading the text. Following this, the number from the formula was multiplied by 
six. To check the readability of the texts, the researcher used the Flesch-Kincaid readability formula.

\section{Reading proficiency:}

Proficient readers exhibit certain qualities and use certain strategies in developing proficiency as discussed in professional journal articles and other educational resources. Proficiency is defined as the ability to construct meaning from text at a reading level higher than the students' age. The research showed the following six universal qualities displayed by proficient readers: understanding the purposes of reading, applying prior knowledge, processing the structures of print, self-monitoring, applying strategies, and reading meaningful text. The strategies examined were metacognition, preparation, organization, elaboration, summarization, and prediction.

\section{How Proficient Readers Read}

In any given grade one can observe a wide range of reading abilities. These abilities are distinguishable through reading levels, comprehension skills, phonemic awareness, and a 
general love for reading. A student may display proficiency in any one of these four areas, but a proficient reader is one that has strong skills in all areas. Proficiency is defined as the ability to construct meaning from text at a reading level higher than the students' age. With this definition in mind, one may wonder, "What makes one student more proficient than another?" The purpose of this paper, based on research published in professional journal articles and other educational resources, is to examine what qualities proficient readers display and what reading and comprehension strategies they use in developing their proficiency.

A recent study shows that readers acquire six qualities that allow them to become proficient (Riley, 1992). Proficiency depends on these qualities working together and creating the elaborate process of reading (Myers, 1991). The first quality Riley (1992) cites is understanding the purposes of reading. Good readers develop an understanding of why they are reading a specific text, decide a goal for their reading such as educational, recreational, and informational, and develop a high level of comprehension (Aarnoutse \& Brand-Gruwel, 1997; Gunning, 1996; Pressley \& Whatnot-McDonald, 1997). It is 
with this understanding of purpose that proficient readers gain ownership of the material and develop a love for reading.

The second quality proficient readers display is applying prior knowledge to print (Riley, 1992). The ability of the readers to use their prior knowledge and apply it to what they are reading will increase their level of comprehension (Pressley \& Whatnot-McDonald, 1997). A student's existing knowledge can be grouped into schemas or units of organized knowledge and used to facilitate the process of "building a connection between what we know and what we do not know" (Gunning, 1996, p. 193). Activating prior knowledge through the use of schemas will not only increase comprehension, but also allows readers to continue to build their repertoire of knowledge (Gunning, 1996) and help them work towards higher reading levels.

The third quality that can be seen in proficient readers is a strong ability to process the structures of print. This means being knowledgeable of letter/sound correspondence, syntactic structures, and semantic associations (Riley, 1992). Letter/sound correspondence refers to a person's level of phonemic awareness. A high level in this area allows students to separate sounds and thus be able to understand and develop literacy 
(Gunning, 1996). Syntactic structures refer to the order of words in a sentence and semantic associations are the meaning of words. These help to make up the structures of the English language and help students make sense of the print (Hahn, 1996). Together with phonemic awareness, syntax and semantics work towards understanding text and building literacy.

The fourth quality Riley (1992) discusses as pertinent to being a proficient reader is self-monitoring. The most common way students can self-monitor is through their use of metacognition (Riley, 1992). "Metacognition or 'thinking about thinking' involves the awareness and regulation of thinking processes" (El-Hindi, 1997, p.10). Myers (1991) states that good readers are aware of how to effectively use their metacognitive strategies in order to develop comprehension. One method that students can use to develop metacognition is to create reading logs to document thought processes as they read text (El-Hindi, 1997). This type of exercise can help students increase both metacognition and reading proficiency.

The fifth ability that proficient readers display is the application of a variety of strategies to comprehend their reading (Riley, 1992). Some of these strategies follow a sequential order 
as the reading process continues. First, students should understand why they are reading a chosen text so they can have a focus for their reading. Second, while reading a text, students develop hypotheses, integrate ideas, and construct conclusions. Finally, good readers will re-read or skim previous sectors of a text to further develop their comprehension (Pressley \& Whatnot-McDonald, 1997). Although these are but a few of the existing strategies available to readers, they work towards helping the student create meaning and comprehension.

The sixth and final aspect of proficient readers is that they read and enjoy a variety of meaningful texts. These texts can range from academic textbooks to fiction or non-fiction books to newspaper articles or magazines to comics (Riley, 1992). Through reading such a wide variety of texts, good readers display a strong passion for reading especially "when the text includes ideas near and dear to their hearts" (Pressley \& Whatnot-McDonald, 1997, p. 450).

Proficiency in reading is distinguishable by certain qualities displayed and applied by the reader. These qualities are purpose, prior knowledge, structures, self-monitoring, strategies, and a love of reading (Riley, 1992). These six attributes all work 
together towards the common goal of building literacy, constructing meaning, and developing comprehension skills. The more that readers develop these qualities, the more reading they will want to do, thus leading them to become more effective readers (Riley, 1992).

Developing literacy is the main goal of any language arts program in schools. It begins at an early age and becomes a continual life long process. Throughout the process, one can see various levels of reading abilities at any age. These levels can range from illiteracy to proficiency. As future educators, we were interested in understanding these various levels and researched how a higher level of proficiency in reading is attained.

Some ways to promote proficiency include a few simple strategies that are easy to implement. First, educators need to find ways to motivate their students to read. This means making the reading meaningful to the students, giving them a choice in the selection of reading materials, and making it fun. Second, educators need to provide many opportunities for their students to read. The more opportunities that students have to read, the more they can use and further develop their reading skills and increase their comprehension. "Comprehension is the main 
purpose of reading. In fact, without it, there is no reading, since reading is the process of constructing meaning from print" (Gunning, 1996, p. 193). The combination of being motivated to read and reading a lot will help students develop a love for reading and increase their comprehension.

Proficiency in reading is a current topic of interest among educators, particularly in California. In order to fully understand the way students can develop their proficiency, further research needs to be conducted on the reading abilities of younger students, specifically students in kindergarten through third grade. Most research to date has been focused on older age students or students below average in reading. Research conducted on students' reading abilities at an early age should be done in combination with assessments on comprehension levels. With more research educators will gain insight in to the ways of promoting proficiency in reading.

\section{Reading proficiency definition}

Torgesen, Houston, Rissman, \& Kosanovich,M (2007) "reading Proficiency at the end of elementary school requires 
that students be Able to identify the words on the page accurately and fluently; that they have enough knowledge and thinking ability to understand, the words,sentences, and paragraphs; and that they be motivated and engaged enough to use their knowledge and thinking ability to understand and learn from the text. We want to emphasize that motivation to understand and learn from text is a critical component of reading comprehension".

National reading panel( 2000)reading proficiency requires According to Three Sets of interrelated skills that develop over time: language and communication, mechanics of reading and context knowledge.

According to the report by the US National Reading Panel (NRP) in 2000 , the skills required for proficient reading are phonological awareness, phonics (sound -symbol correspondence), fluency, Vocabulary, and text comprehension.

- Phonemic awareness: the ability to distinguish and manipulate the individual sounds of language the broader term , phonological awareness ,also include rhymes, syllables, onsets and rimes. 
- phonics : method that stresses the acquisition of letter sound correspondences and their use in reading and spelling . this helps beginning readers understand how letters are linked to sound (phonemes),patterns of letter-sound correspondences and spelling in English, and how to apply this knowledge when they read.

- Fluency : the ability to read orally with speed, accuracy, and vocal expression . the ability to read fluently is one of several critical factors necessary for reading comprehension. If a reader is not fluent, it may be difficult to remember what has been read and to relate the ideas expressed in the text to his or her background knowledge. This accuracy and automaticity of reading serves as a bridge between decoding and comprehension.

-Vocabulary: a critical aspect of reading comprehension is development. When a reader encounters an un familiar vocabulary words in print and decodes it to derive its spoken pronunciation, the reader understands the word if it is in the reader's spoken vocabulary.

Otherwise, the reader, must derive the meaning of the word using another strategy such as context. 
Reading comprehension: the NRP describes comprehension as -complex cognitive process in which a reader intentionally an interactively engages with the text. Reading comprehension is heavily dependent on skilled word recognition and decoding. Oral reading fluency, a well developed vocabulary and active engagement with the text.

According to the national reading panel (2000), there are five vital components of effective reading instruction. The components are scientifically, and are the core, critical skills students need to learn in order to become proficient readers . These essential components are phonemic awareness, phonics, vocabulary development, reading fluency, and reading comprehension. After an extensive and objective research review, the national reading panel (N RP) completed a meta analysis of each of these components determined to be essential when teaching children to read.

\section{Phonemic awareness:}

Phonemic awareness is a term that refers to the ability to hear sounds in spoken language. Tindall and Nisbet (2010) defined it as the ability to hear and manipulate individual sounds in words. For example, the word cat has three phonemes, /c/ /a/ /t/ while clock has four, /c/ /1/ /o/ / k/. 
Activities practicing phonemic awareness are completely auditory however, in the later continuum of phonemic awareness auditory activities move to connect to printed activities . Listening for the number of sounds , identifying beginning, middle and ending sounds, and manipulating sounds to make new words are all types of activities that promote phonemic awareness.

\section{Phonics:}

Phonics instruction helps students understand the alphabetic principle or to understand the connection between the symbols of written language and the sounds of the spoken language. Children who understand phonics are able to recognize and predict the relationships between letters and sounds. They are able to identify familiar words and decode unfamiliar ones. Phonics instruction typically occurred in the beginning stages of reading in English when students learned how sounds and letters corresponded to one another and used this knowledge to read and spell (Tindall \& Nisbet, 2010). A child's knowledge of letters, ability to distinguish syllables, rhymes, phonemes, and understanding of phoneme-grapheme 
correspondence were all variables that influenced the acquisition of language skills (Whitehurst \& Lonigan, 1998).

\section{. Fluency:}

While some educators think of fluency as a student's ability to read quickly, the National Reading Panel (2000) defined it as being able to read orally with speed, accuracy, and proper expression. Fluency was identified as an essential factor for reading comprehension. If text was read in a laborious and inefficient manner, it was difficult for the child to remember what had been read, and to relate the ideas expressed in the text to his or her background knowledge (National Reading Panel, 2000). The panel looked at two instructional practices for teaching fluency. One was guided repeated oral reading, and the other was independent silent reading. Based on the research the panel studied, it was determined that guided repeated oral reading procedures had a significant and positive effect on word recognition, fluency, and comprehension. The results determined by the study applied to all students, good readers as well as students with reading difficulties. One shortfall to the panel's findings was that there were no multiyear studies providing information on the relationship between guided oral readings and the emergence of fluency (National Reading Panel, 
2000). When looking at independent silent reading, the panel was unable to find a positive relationship between student reading achievement and the programs and instruction that encouraged large amounts of independent reading.

\section{Reading comprehension:}

Reading comprehension is a complex process that involves integrating information, making inferences, and constructing meaning (Bellinger and DiPerna, 2011). Today, reading comprehension is thought to be an active and intentional practice versus a passive practice as it was years ago (Bellinger and DiPerna, 2011). Students need to be involved in the reading process first hand, and actively read for meaning by making connections, inferring, synthesizing, and predicting. Comprehension is dependent upon several skills including fluency, semantic skills, phonological skills, memory processing skills, vocabulary, inferring, grammatical structure, prior knowledge, and verbal ability (Cain \& Oakhill, 2006). The National Reading Panel (2000) stated that reading comprehension is a critical component of children's learning, and in order for children to achieve growth in learning, they must be able to comprehend text. Without comprehension, the 
goal of reading is not met, and children are not successful readers. In order to achieve a high level of comprehension, basic reading skills need to be mastered. Due to this importance of reading comprehension on overall learning of children, it is no surprise that Cain and Oakhill (2006) found that children with poor comprehension skills made fewer gains than children with good comprehension. Comprehension is the ultimate goal in reading and without an understanding of reading, achievement is not made. The National Reading Panel (2000) affirms that reading comprehension is an essential component of increasing knowledge and it also assists in the enjoyment of reading because if children do not understand what they read, they will not have the desire to read. DeKonty and Modla (2009) disagree with the notion that fluency frees up cognitive use for comprehension, and argue that the result of automaticity in word recognition does not necessarily attribute to comprehension. It is important for teachers to integrate fluency practices into all aspects of reading (Bashir \& Hook, 2009).

\section{Pilot study}

The Reading proficiency test was pre administered to a group of 30 third year prep school students rather than the 
participants of the study. Results of test indicated that the students are weak in reading proficiency skills(phonemic awareness, phonics, reading comprehension, vocabulary and fluency)

\section{The statement of the problem}

In the light of the previous presentation and the pilot study. Students in the third year prep stage have some difficulties in the reading proficiency. The present study tries to develop reading proficiency skill through the use of extensive reading remedial program. The problem can be formulated in the following main question .

- -What is the effectiveness of the extensive reading remedial program in developing third year prep stage students ' reading proficiency?

main question can be subdivided into the following questions: This

- What are the appropriate extensive reading activities that can develop third year prep stage students reading proficiency skill? 
- -How can an extensive reading remedial program be designed to develop students ' reading proficiency skills?

- -What is the effect of the designed program on developing student's reading proficiency kills?

\section{. Procedures of the research:}

1. Reviewing the literature related to the research variables.

2. Designing the test and the framework of reading extensive reading remedial program.

3. Submitting the test and the program to jury members to validate them.

4. Administering pre-test and the program to the participants.

5. Conducting the statistical analysis of the data.

6. Discussing and interpreting results.

7. Giving recommendations and suggestions for further studies. 


\section{Hypotheses:}

The following hypotheses were tested.

1- There would be a statistical significant difference between mean scores of the control and experimental groups of the reading proficiency test in favor of the post-performance.

2- There would be a statistical significant difference between the mean scores of the experimental group in the pre and post performance of the reading proficiency test.

3 - there is an effectiveness of the extensive reading remedial program in developing third year prep stage students English reading proficiency.

\section{Aim of the research:}

- This study aimed at indicating the effectiveness of the extensive reading remedial program in developing reading proficiency skills among prep stage students.

\section{The significance of the research :}

- Providing students with a list of extensive reading activities appropriate to prep stage students. 
- Providing the teachers and researchers with appropriate techniques for teaching reading skills.

- Helping students to develop their reading proficiency .

\section{Delimitation of the research:}

The participants were 60 students from third year prep stage students were selected to participate in the program.

- The reading material of pre- post oral reading through which the miscues can be identified and analyzed.

- Some reading activities that may help students to develop reading skills and become proficient readers. The reading texts are varied in the length and slightly above the level of the students but at a level they are able to understand.

- The Components of reading proficiency are Phonemic awareness, phonics, vocabulary, fluency , and reading comprehension.

the duration of the study was 6 weeks.

\section{Definition of Terms:}

\section{. Reading proficiency:}

"Reading proficiency" actually refers to all of the thinking behind reading; what happens in our brains before, 
during, and post reading. The different ways in which we think critically about what we read is the skill now being measured. Proficient readers preview text, make predictions, activate prior knowledge (commonly referred to as schema), and even set a purpose for their reading (what am I trying to figure out?).

https://www.gemmlearning.com/blog/education trends/commoncore-state-standards/reading-proficiency-for-ccss/

\section{Extensive reading}

Extensive Reading (ER) is an approach to second language reading. When learners read extensively, they read very easy, enjoyable books to build their reading speed and fluency. Another way to say this is students learn to read by actually reading rather than examining texts by studying the vocabulary, grammar and phrases. It is instructive to compare Intensive Reading (IR) with Extensive Reading. https://www.er-central.com/contributors/learn-about-extensive-readingand-listening/what-is-extensive-reading/

\section{Research Design:}

The researcher adopted quasi experimental design of the two groups 
Educational and Psychological Studies Faculty of Education Journal Zagazig University Vol. (37) No. (114), Part(1), January 2022

Instruments and material of the study:

1-The suggested program

2-Reading Proficiency test

\section{Results}

The results of the present study showed that third year prep stage students benefited from the extensive reading- remedial program. The majority of the experimental group subjects could improve their reading proficiency kills. Moreover, they could develop better social, interactive learning skills.

\section{Recommendations:}

Based on the results, it is recommended that:

a)EFL In-service-teachers should be trained on how to develop remedial programs for prep stage students.

b) EFL In-service-teachers should utilize this remedial programs for prep stage students.

c) Curriculum designers should consider this program on designing EFL textbooks. 


\section{Suggested future research:}

1. Further research should be conducted to identify the effects of using remedial programs on developing student $\mid$ teacher classroom interactions.

2. Further researches should be conducted to identify the effects of using remedial programs on improving learners' writing skills.

\section{References:}

Anderson, R.C., Hiebert, E.H., Scott, J.A., \& Wikinson, I.A. (1985).

Becoming a nation of readers: the report of the commission on reading. Washington, DC: National Institute of Education. Retrieved from http/ files.eric.ed.gov/ Aarnoutse, C., \& Brand-Gruwel, S. (1997). Improving reading comprehension strategies through listening. Educational Studies, 23(2), 209-228. 
Allington, R. (2001). What really matters for struggling readers?

Designing research-based programs. New York:

Longman.

Allington, R.L. (1977). If they don't read much, how they ever gonna get good? Journal of Reading, 21, 57-61. Retrieved from http://www.jstor.org/stable/40009862

Alderson, J. C. and Urquhart, A. H. (1984). Reading in a Foreign Language. London: Longman.

Bashir, A.S., \& Hook, P.E. (2009). Fluency: a key link between word identification and comprehension. Language, Speech, and Hearing Services in Schools, 40, 196-200. doi:0161$1461 / 09 / 4002-0196$

Bell, T. (2001). Extensive reading: Speed and comprehension. The Reading Matrix, 1. Retrieved October 28, 2006, from http://www.readingmatrix.com/archives/archives_vol1_n o1.html

Bernhardt, E. B. (1991). Reading development in a second language: Theoretical, empirical and classroom perspectives. Norwood, NJ: Ablex. 
Cain, K., \& Oakhill, J. (2006). Assessment matters: issues in the measurement of reading comprehension. British Journal of Educational Psychology, 76, 697-708. doi:10.1348/000709905X69807

Cho, K. and Krashen, S. (1994). Acquisition of vocabulary from the Sweet Valley Kids series: Adult ESL acquisition. Journal of Reading, 37, 8, 662-667.

Constantino, R. (1994). Pleasure reading helps, even if readers don't believe it. Journal of Reading, 37, 6, 504-505.

Day, R. R. and Bamford, J. (1998). Extensive reading in the second language classroom. Cambridge: Cambridge University Press.

Day, R. R. and Bamford, J. (2002). Top ten principles for teaching extensive reading. Reading in a Foreign Language, 14, 2, 136-141.

Day, R. R., \& Bamford, J. (1998). Extensive reading in the second language classroom. Cambridge: Cambridge University Press. 
Day, R. R., Omura, C. and Hiramatsu, M. (1991). Incidental EFL vocabulary learning and reading. Reading in a Foreign Language, 7, 2, 541-551.

Bellinger, J., \& DiPerna, J. (2011). Is fluency-based story retell a good indicator of reading comprehension? Psychology in the Schools, 48, 416-425. doi:10.1002/pits.20563

Elley, W. B. and Mangubhai, F. (1981a). The impact of a book flood in Fiji primary schools. Wellington: New Zealand Council for Educational Research and Institute of Education.

Elley, W. B. and Mangubhai, F. (1981b). The long-term effects of a book flood on children's language growth. Directions, 7, 15-24.

Elley, W. B. and Mangubhai, F. (1983). The impact of reading on second language learning. Reading Research Quarterly, 19, 1, 53-67.

El-Hindi, A. E. (1997). Connecting reading and writing: College learners' metacognitive awareness. Journal of Developmental Education, 21(2), 10-16. 
Elley, W. B. (1991). Acquiring literacy in a second language:

The effect of book-based programs. Language Learning, $41,3,375-411$.

Eskey, D. (1988). Holding in the bottom: An interactive approach to the language problems of second language readers. In P. Carrell, J. Devine, \& D. Eskey (Eds.), Interactive approaches to second language reading (pp. 93-100). Cambridge: Cambridge University Press

Ehri, L. C. (1995). Phases of development in learning to read words by sight. Journal of Research in Reading, 18, 116125 .

Grabe, W. (1988). Reassessing the term "interactive." In P. Carrell, J. Devine, \& D. Eskey (Eds.), Interactive approaches to second language reading (pp. 56-70). Cambridge: Cambridge University Press.

Grabe, W. (1995b). Why is it so difficult to make extensive reading the key component of L2 reading instruction? Paper presented at the Reading Research Colloquium, Annual TESOL Convention, Long Beach, CA. 
Grabe, W. and Stoller, F (2002). Teaching and researching reading. Harlow, UK: Longman.

Gunning, T. G. (1996). Creating reading instruction for all children $\left(2^{\text {nd }}\right.$ ed.). Needham Heights, MA: Allyn \& Bacon.

Harris, A. J., \&Sipay, E. R. (1985). How to increase reading ability: A guide to developmental and remedial methods (8th ed.). White Plains, NY: Longman.

Hayashi, K. (1999). Reading strategies and extensive reading in EFL classes. RELC Journal, 30, 2, 114-132.

Hedge, T. (1985). Using readers in language teaching. London: Macmillan.

Hirsh, D. and Nation, I. S. P. (1992). What vocabulary size is needed to read unsimplified texts for pleasure? Reading in a Foreign Language, 8, 689-696.

Hitosugi, C. and Day, R. R. (2004). Extensive reading in Japanese. Reading in a Foreign Language, 16, 1, 91-110

Hu, M. and Nation, I. S. P. (2000). Unknown vocabulary density and reading comprehension. Reading in a Foreign Language, 13, 1, 403-430. 
Hahn, M. (1996). The structure of language. Language Acquisition and Development Reader. Domincan College, San Rafael, CA.

Krashen, S. D. (1982). Principles and practice in second language acquisition. New York: Prentice Hall.

Krashen, S. D. (1993). The power of reading: Insights from the research. Englewood, CO: Libraries Unlimited.

Kuhn, M.R., Schwanenflugel, P.J., Morris, R.D., Morrow, L.M., Woo, D.G., Meisinger, E.B., Sevcik, R.A., Bradley, B.A., \& Stahl, S.A. (2006). Teaching children to become fluent and automatic readers. Journal of Literacy Research, 38, 357-387.

Retrieved from

http://web.ebscohost.com.pluma.sjfc.edu

Kuhn, M. R., \& Stahl, S. A. (2003). Fluency: A review of developmental and remedial practices. Educational Psychology, 95, 3-21.

Kuhn, M., Schwanenflugel,E., \&Meisinger, E. (2010). Aligning theory and assessment of reading fluency:automaticity, 
prosody, and definitions of fluency. Reading Research Quarterly, 45, 230-251. doi:10.1598/RRQ.45.2.4

Laufer, B. (1989).What percentage of text-lexis is essential for comprehension? In C. Lauren and M. Nordman (Eds.), Special Language: From Humans Thinking to Thinking Machines, Clevedon: Multilingual Matters.

LaBerge, D., \& Samuels, S. J. (1974). Toward a theory of automatic information processing in reading. Cognitive Psychology, 6, 293-323.

LaBerge, D., \& Samuels, S.J. (1974). Toward a theory of automatic information processing in reading. Cognitive Psychology, 6, 293-323. Retrieved from http://web.ebscohost.com.pluma.sjfc.edu

Lai, F.-K. (1993). The effect of a summer reading course on reading and writing skills. System, 21, 87-100. Mason, B. and Krashen, S. (1997). Extensive reading in English as a foreign language. System, 25, 1, 99-102.

Mc Quillan, J. (1994). Reading versus grammar: What students think is pleasurable for language acquisition. Applied Language Learning, 5, 2, 95-100. 
Myers, S. S. (1991). Performance reading comprehensionproduct or process. Educational Review, 43(3), 257-273.

Mikulecky, B. (1990). A short course in teaching reading skills. Reading, MA: Addison-Wesley.

National reading panel.(2000).Teaching children to read: An evidence.

Based assessment of the scientific research literature on reading and its implications for reading instruction. Washington DC:

National Institute of Child Health and Human Development

National Reading Panel. (2000). Report of the National Reading Panel: Teaching children to read. Report of the subgroups. Washington, DC: US Department of Health and Human Services, National Institutes of Health.

Nation, I. S. P. (2005). Teaching Reading and Writing. Student Notes Distribution Center. School of Linguistics and Applied Language Studies. Victoria University of Wellington.

Nation, I. S. P. (2001). Learning vocabulary in another language. Cambridge: Cambridge University Press. 
Nassaji, H. (2003). Higher-level and lower-level text processing skills in advanced ESL reading comprehension. The Modern Language Journal, 87, 261-276.

Nuttall, C. (1996). Teaching reading skills in a foreign language (2nd edition). Oxford: Heinemann.

O'Connor, R., White, A., \& Swanson, H.L. (2007). Repeated reading versus continuous reading: influences on reading fluency and comprehension. Council for Exceptional Children, 74, 31-46. Retrieved from http://web.ebscohost.com.pluma.sjfc.edu

Paige, D.D. (2011). 16 minutes of "eyes-on-text" can make a difference: whole class choral reading as an adolescent fluency strategy. Reading Horizons 51, 1-15. Retrieved from http://web.ebscohost.com.pluma.sjfc.edu

Paran, A. (1996). Reading in EFL: Facts and fictions. English Language Teaching Journal, 50, 25-34.

Raskinski, T.V. (2003). Parental involvement: key to leaving no child behind in reading. The New England Reading Association Journal, 39, 1-5. Retrieved from http://web.ebscohost.com.pluma.sjfc.edu 
Pressley, M., \& Wharton-McDonald, R. (1997). Skilled comprehension and its development through instruction. School Psychology Review, 26(3), 448-467.

Richards, J. C. and Schmidt, R. (2002). Longman dictionary of language teaching and applied linguistics (3rd edition). London: Longman.

Renandya, W. A., \& Jacobs, G. M. (2002). Extensive reading: Why aren't we all doing it? In J. C. Richards \& W. A. Renandya (Eds.), Methodology in language teaching: An anthology of current practice (pp. 295-302). Cambridge: Cambridge University Press.

Riely, J. D. (1992). Using the proficient reader protocol to evaluate middle school reading behaviors. The Clearing House, 66(1), 41-44.

Rasinski, T. V. (2004). Creating fluent readers. Educational Leadership, 61, 46-51.

Robb, T. N. and Susser, B. (1989). Extensive reading vs. skills building in an EFL context. Reading in a Foreign Language, 5, 2, 239-251. 
Rupley, W., Blair, T., \& Nichols, W. (2009). Effective reading instruction for struggling readers: the role of direct/explicit teaching. Reading \& Writing Quarterly, 25, 125- 138. doi: 10.1080/10573560802683523

Samuels, S.J. (1979). The method of repeated readings. The Reading Teacher, 32, 403-408. Retrieved from http://web.ebscohost.com.pluma.sjfc.edu

Samuels, S. J. (1994). Toward a theory of automatic information processing in reading, revisited. In R. B. Ruddell, M. R. Ruddell, \& H. Singer (Eds.), Theoretical models and processes of reading (4th ed.) (pp. 816-837). Newark, DE: International Reading Association.

Stanovick, K. (2000). Progress in understanding reading: Scientific foundations and new frontiers. New York: Guilford Press.

Sheu, S. P.-H. (2003). Extensive reading with EFL learners at beginning level. TESL Reporter, 36, 8-26

Therrien, W. J. (2004). Fluency and comprehension gains as a result of remedial reading. Remedial and Special Education, 25, 252-261. 
Torgesen,J.,Houston,D, Rissman, L.,\& Kosanovich, M.(2007).Teaching All students to read in elementary schools :A guide forPrincipal .Port Smouth ,NH: Rmc research corporation, Center on instruction.(p1).

Tindall ,E.\& Nisbet, D.(2010).Exploring the essential components of Reading .Journal of adult Education information series, 39(1),1-9.

Whitehust,G.J.,\&Lonigan, C.J.(1998).Child development and emergent Literacy. Child development , 69(3),848-872.

Wixson „K.,Peters,C.,Weber,E \& Roeber,E.(1987). New direction instate Wide reading assessment. The reading teacher ,40,749-754(Citing the new definition of reading for Michigan, Retrieved from http://WWW.edu palce.com /vdy/resl teach /pdf.html.

Young, C. \&Rasinski, T. (2009). Implementing readers theatre as an approach to classroom fluency instruction. The Reading Teacher, 63, 4-13. doi:10.1598/RT.63.1.1 